\author{
Danang Wahyu Muhammad, Ahdiana Yuni Lestari \\ Fakultas Hukum Universitas Muhammadiyah Yogyakarta \\ danangwahyudumy.ac.id
}

Naskah Masuk: 7 November 2015 Naskah Diterima: 30 November 2015

\title{
KONSEP PENGATURAN PENJAMINAN SIMPANAN NASABAH PADA BANK SYARIAH
}

\section{ABSTRAK}

Lembaga Penjamin Simpanan (LPS) belum mempunyai skema syariah sebagai pembeda skema penjaminan dana masyarakat yang berbasis syariah. Sementara itu, Peraturan Pemerintah yang sudah ada, yaitu PP No. 39 Tahun 2005 tentang Penjaminan Simpanan Nasabah Bank Berdasarkan Prinsip Syariah sifatnya sangat sederhana sehingga tidak mencukupi dan tidak tuntas. Berdasar latar belakang tersebut, maka rumusan masalah dalam dalam penelitian ini adalah "Bagaimana konsep pengaturan penjaminan simpanan nasabah pada Bank Syariah?" Tujuan penelitian ini adalah untuk membuat konsep tentang pengaturan penjaminan simpanan nasabah pada bank syariah. Dengan menggunakan metode pendekatan perundang-undangan dan konseptual, penelitian akan mengkaji bahan-bahan hukum, baik bahan hukum primer, bahan hukum sekunder dan bahan-bahan non hukum. Analisis dalam penelitian ini menggunakan metode preskriptif. Kesimpulannya adalah prinsip operasional perbankan di Indonesia terdapat dua jenis bank, yaitu bank konvensional dan bank syariah, di mana ke dua jenis bank tersebut menggunakan sistem yang berbeda. Oleh karena itu secara prinsip perlu dibedakan lembaga yang menjamin simpanan nasabahnya. Hal ini berdasarkan pada pertimbangan: Bank syariah mengharamkan bunga dan oleh karena itu tidak menggunakan mekanisme bunga dalam operasionalnya, maka seharusnya Lembaga yang menjamin simpanan nasabahnya pun juga tidak menggunakan mekanisme bunga. Bank syariah dalam operasionalnya menggunakan akad yang sudah ditentukan dalam fiqih Islam, maka Lembaga yang menjamin simpanan nasabahnya pun juga harus mendasarkan pada akad yang ditentukan dalam fiqih Islam. Bank syariah terikat dengan ketentuan apa yang boleh dilakukan dan tidak boleh dilakukan berdasarkan ketentuan agama Islam, maka Lembaga yang 


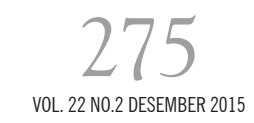

menjamin simpanan nasabahnya pun juga harus mendasarkan pada ketentuan yang sama. Dengan demikian akan ada konsistensi antara bank syariah dengan lembaga yang menjamin simpanan dana yang ada pada bank syariah, yang pada akhirnya akan menjamin perlindungan terhadap nasabah yang ingin menjalankan agama dengan baik dan benar.

Kata Kunci: Lembaga Penjamin Simpanan, Nasabah, Bank Syariah

\section{ABSTRACT}

Fund Guarantor Institution (LGI) does not yet have Syariah scheme as a distinguishing feature of Sharia-based society fund guarantee. Meanwhile, the existing Government Regulation, that is PP No. 39 Year 2005 about Bank Customer Fund Guarantee based on Sharia Principles, is very simple so that it is not sufficient and does not cover Islamic Banks. Based on the background, the problem formulation in this research is "What is the concept of customer fund guarantee regulation like in Islamic Banks?" The objective of this research is to make a concept about customer fund guarantee regulation in Islamic Banks. With law and conceptual approach method. As a doctrinal law research, this research will only review legal materials; primary legal materials, secondary legal materials, and non-legal materials. The analysis of this research uses prescriptive method.The conclusion of the research is that in Banking Operation Principles in Indonesia there are two types of banks; conventional and Islamic bank, where both types use different systems. As a consequence, in principle, the institution that guarantees the customer fund should be distinguished. This is based on some considerations: Islamic Banks proscribes bank interest, because of that they do not use bank interest mechanism in its operation, therefore the institution that guarantees its customer fund should not use bank interest mechanism. In its operational systems, Islamic Banks use covenants that have been determined according to Islamic Fiqh, so the institution that guarantees its customer fund should base its operation system to the covenant that is based on Islamic Fiqh. Islamic Banks are limited by what may be done and what may not be done based on Islamic Fiqh, determination, so the institution that guarantees its customer fund should base its operational on the same determination. Therefore, there will be a consistency between Islamic Banks and the institution that guarantees its customer fund in Islamic Banks which at the end will guarantee protection towards the customers who are willing to perform Islamic religious duty in a good and correct way.

Keywords: Fund Guarantor Institution, Customer, Islamic Bank.

\section{A. LATAR BELAKANG}

Lembaga Penjamin Simpanan (LPS), adalah lembaga negara yang dibentuk menurut UU No. 24 Tahun 2004 sebagaimana telah diubah dengan Peraturan Pemerintah Pengganti UU No. 3 Tahun 2008 dan telah disahkan menjadi UU dengan UU No. 7 Tahun 2009. LPS mempunyai fungsi menjamin simpanan nasabah bank; dan turut aktif dalam memelihara stabilitas sistem perbankan sesuai dengan kewenangannya (Pasal 4 UULPS). Fungsi yang pertama dari LPS tersebut disebut sebagai Penjaminan Simpanan Nasabah Bank (Pasal 1 angka 8 UULPS).

Pada kenyataannya saat ini di Indonesia, berdasarkan sistem operasionalnya terdapat dua jenis bank, yaitu bank konvensional, yaitu bank yang mendasarkan pada UU No. 7 Tahun 1992 sebagaimana telah diubah dengan UU No. 10 Tahun 1998; dan bank syariah, yaitu bank yang mendasarkan pada UU No. 21 tahun 2008. Ada perbedaan yang mendasar antara bank konvensional dengan bank syariah, yaitu bank syariah dalam operasionalnya tidak menggunakan mekanisme bunga, melainkan menggunakan mekanisme yang dibenarkan menurut hukum Islam. 


\section{6}

JURNAL MEDIA HUKUM

Dalam Pasal 8 ayat (1) UULPS ditentukan bahwa setiap Bank yang melakukan kegiatan usaha di wilayah Negara Republik Indonesia wajib menjadi peserta Penjaminan. Dengan mendasarkan pada ketentuan pasal tersebut, maka penjaminan simpanan nasabah bank meliputi juga simpanan yang ada pada bank syariah. Hal ini dapat diketahui dari bunyi Penjelasan Pasal 4 huruf a UULPS, yaitu penjaminan simpanan nasabah penyimpan meliputi pula penjaminan bentuk yang setara dengan simpanan bagi bank yang menggunakan prinsip syariah.

Berkaitan dengan hal di atas, maka pada tanggal 12 Oktober 2005 telah ditetapkan PP No. 39 Tahun 2005 tentang Penjaminan Simpanan Nasabah Bank Berdasarkan Prinsip Syariah. Dalam Pasal 2 PP tersebut menentukan bahwa LPS, menjamin simpanan nasabah bank berdasarkan Prinsip Syariah sesuai dengan ketentuan dalam UU Nomor 24 Tahun 2004 tentang LPS. Dalam Penjelasan pasal tersebut dinyatakan bahwa LPS menjamin Simpanan nasabah dari bank berdasarkan Prinsip Syariah, baik bank umum dan bank perkreditan rakyat yang melaksanakan kegiatan usaha berdasarkan Prinsip Syariah, maupun Unit Usaha Syariah (UUS) dari bank konvensional.

PP No. 39 Tahun 2005 tentang Penjaminan Simpanan Nasabah Bank Berdasarkan Prinsip Syariah hanya terdiri dari1 bab dan 4 (empat) Pasal dan hanya mengatur hal-hal yang bersifat sangat umum. Bab I berisi tentang Ketentuan Umum, dimana dalam Pasal 1-nya berisi tentang beberapa pengertian umum. Pasal 2 berisi tentang kewenangan LPS untuk menjamin simpanan nasabah bank berdasarkan Prinsip Syariah. Pasal 3 berisi tentang jenis-jenis simpanan syariah dan Pasal 4 berisi ketentuan penutup.

Berkaitan dengan bank syariah adalah bank yang bersifat khusus, di mana akan selalu berkaitan dengan halal dan haram sebagaimana yang berlaku dalam hukum Islam, maka pengaturan tentang penjaminan simpanan nasabah bank berdasarkan prinsip syariah yang terdapat dalam PP No. 39 Tahun 2005 yang bersifat sangat sederhana tersebut menjadi tidak mencukupi. Oleh karena itu, premi-premi perbankan syariah (deposit insurance) yang disetorkan kepada LPS oleh bank syariah sampai saat ini belum dikelola secara syariah. Penyebabnya, LPS belum mempunyai skema syariah sebagai pembeda skema penjaminan dana masyarakat yang berbasis syariah. Ketua Umum Ikatan Ahli Ekonomi Islam (IAEI), Mustafa Edwin N, mengatakan tak adanya skema syariah pada LPS dalam jangka panjang akan menjadi bom waktu bagi dunia perbankan syariah nasional, karena akan menurunkan kepercayaan nasabah terhadap bank syariah (http://zonaekis.com/aturan-skemasyariah-memerlukan-lembaga-penjamin-simpananlps/).

\section{B. RUMUSAN MASALAH}

Berdasarkan latar belakang di atas, maka dapat dirumuskan permasalahan sebagai berikut: "Bagaimana konsep pengaturan penjaminan simpanan nasabah pada Bank Syariah?"

\section{TEMUAN YANG DITARGETKAN}

Temuan yang ditargetkan dalam penelitian ini adalah perumusan kaidah-kaidah atau konsep 
tentang pengaturan penjaminan nasabah pada bank syariah dalam bentuk Rancangan Peraturan Pemerintah.

\section{TUJUAN DAN MANFAAT PENELITIAN}

\section{Tujuan Penelitian}

Tujuan penelitian ini adalah untuk membuat konsep tentang pengaturan penjaminan simpanan nasabah pada bank syariah.

\section{Manfaat Penelitian}

Penelitian ini sangat urgen mengingat adanya kewajiban bank syariah untuk menjamin nasabahnya di LPS. Sementara itu pengaturan LPS yang dituangkan dalam PP No. 39 Tahun 2005 bersifat sangat sederhana dan tidak mencukupi karena tidak adanya skema syariah pada LPS. Dalam jangka panjang hal ini akan menjadi bom waktu bagi dunia perbankan syariah nasional, karena akan menurunkan kepercayaan nasabah terhadap bank syariah (http://zonaekis.com/aturanskema-syariah-memerlukan-lembaga-penjamin-simpanan lps/). Oleh karena itu perlu penelitian dan perlu dirumuskan mengenai konsep pengaturan penjaminan nasabah pada bank syariah dalam bentuk Peraturan Pemerintah.

\section{E. METODE PENELITIAN}

\section{Jenis Penelitian}

Penelitian ini merupakan penelitian hukum normatif dengan menggunakan metode studi pustaka. Pencarian bahannya didasarkan pada bahan-bahan hukum primer, sekunder, tersier dan wawancara dengan ahli fikih muamalah sebagai narasumber. Penelitian ini akan mengkaji asasasas atau prinsip-prinsip keadilan, amanah dan tidak mengandung riba yang merupakan prinsipprinsip yang berlaku pada Bank Syariah dan kemudian disusun dalam sebuah konsep pengaturan tentang penjaminan simpanan pada bank syariah.

\section{Pendekatan}

Dalam penelitian ini menggunakan pendekatan perUUan dan pendekatan konseptual. Pendekatan perUUan digunakan, karena penelitian ini akan mengkaji suatu perUUan yang berkaitan dengan bank syariah dan penjaminan simpanan. Dalam melakukan kajian, peneliti menggunakan bahan-bahan hukum primer, yang berupa peraturan-peraturan yang bersifat mengikat (Johnny Ibrahim, 2007: 301-303; Peter Mahmud Marzuki, 2005: 96-97).

Pendekatan konseptual digunakan untuk memaknai keadilan, amanah dan bebas riba, yang merupakan prinsip-prinsip yang berlaku dalam muamalah, yang merupakan suatu konsep yang bersifat abstrak, oleh karena itu perlu dijabarkan dan dicari unsur-unsurnya sehingga dapat dirumuskan dalam suatu peraturan pemerintah. Berdasarkan kajian dengan pendekatan konseptual ini nantinya akan melahirkan konsep tentang pengaturan penjaminan simpanan nasabah pada bank syariah 


\section{8}

JURNAL MEDIA HUKUM

\section{Konsep}

Bank Syariah, menurut ketentuan UU No. 21 Tahun 2008 tentang Perbankan Syariah, adalah bank yang menjalankan kegiatan usahanya berdasarkan Prinsip Syariah dan menurut jenisnya terdiri atas Bank Umum Syariah dan Bank Pembiayaan Rakyat Syariah.

Keadilan, amanah, tidak mengandung riba adalah prinsip-prinsip yang berlaku dalam hukum Islam yang harus dipatuhi oleh Bank Syariah.

\section{Teknik Pengumpulan Bahan Hukum}

Dalam penelitian hukum normatif ini dilakukan dengan studi pustaka, yaitu peneliti melakukan kegiatan-kegiatan pencarian, penelusuran dan membaca secara mendalam terhadap semua literatur, yang disebut dengan bahan-bahan hukum berupa bahan hukum primer, bahan hukum sekunder, dan bahan hukum tersier yang terkait dengan obyek penelitian. Bahan hukum primer merupakan bahan hukum yang bersifat autoritatif artinya mempunyai otoritas, yang terdiri dari peraturan perUUan, catatan resmi atau risalah dalam pembuatan perauturan perUUan (Peter Mahmud Marzuki, 2005: 141). Bahan-bahan hukum primer dalam penelitian ini, secara konkrit dapat dijabarkan sebagai berikut:

a. bahan hukum primer, yang berupa peraturan perUUan, yaitu:

1) UU No. 7 Tahun 1992 tentang Perbankan sebagaimana telah diubah dengan 10 Tahun 1998;

2) UU No. 23 Tahun 1999 tentang Bank Indonesia, sebagaimana telah diubah dengan UU No. 3 Tahun 2004;

3) UU No. 3 tahun 2008 tentang Lembaga Penjamin Simpanan sebagaimana telah diubah dengan UU No. 7 tahun 2009;

4) UU No. 21 Tahun 2008 tentang Perbankan Syariah, beserta Naskah Akademik dan Risalah Pembahasannya; dan

5) UU No. 21 tahun 2011 tentang Otoritas Jasa Keuangan.

6) Al-Qur'an dan As-Sunnah.

7) Fatwa-fatwa Dewan Syariah Nasional.

8) Peraturan perUUan lain yang berkaitan dengan obyek penelitian.

b. Bahan hukum sekunder adalah semua publikasi tentang hukum yang bukan merupakan dokumen-dokumen resmi (Peter Mahmud Marzuki, 2005: 141), yang meliputi buku-buku teks, jurnal-jurnal hukum, artikel baik di surat kabar maupun di internet, makalah-makalah yang disampaikan dalam pertemuan ilmiah dan seminar, yang dapat digunakan untuk menganalisis dan membantu memahami bahan-bahan hukum primer (Ronny Hanitijo Soemitro, 1988: 12).

c. Bahan hukum tersier adalah bahan-bahan hukum yang dapat menjelaskan bahan hukum hukum primer dan bahan hukum sekunder (Soerjono Sukanto dan Sri Mamudji, 2002: 1415; Peter Mahmud Marzuki, 2005: 163-164). 
Untuk mendukung dan untuk mendapatkan penjelasan lebih lanjut tentang bahan-bahan hukum di atas, peneliti melakukan wawancara dengan beberapa nara sumber yang dianggap tahu dan ahli tentang obyek penelitian. Nara sumber dalam penelitian ini adalah ahli fikih muamalah.

\section{Analisis Data}

Penelitian ini merupakan penelitian hukum normatif yang mendasarkan pada hasil studi kepustakaan dan wawancara dengan narasumber. Bahan-bahan hukum yang diperoleh selama proses penelitian dan hasil wawancara dengan narasumber akan diolah melalui proses penalaran hukum yang logis dan kemudian dilakukan analisis. Dalam penelitian ini analisis dilakukan dengan menggunakan metode preskriptif (Peter Mahmud Marzuki, 2005: 68), yaitu melakukan studi terhadap bahan-bahan hukum yang sudah dikumpulkan dan kemudian dikaji dengan prinsipprinsip hukum Islam, yaitu keadilan, amanah dan bebas dari riba sehingga akan dapat ditarik kesimpulan tentang apa yang seharusnya diatur dalam Peraturan Pemerintah tentang penjaminan simpanan nasabah pada bank syariah.

\section{F. HASIL PENELITIAN DAN ANALISIS}

Penjaminan simpanan nasabah bank dilakukan oleh suatu lembaga yang disebut dengan Lembaga Penjamin Simpanan (LPS). Menurut ketentuan Pasal 4 Undang-Undang Nomor: 24 Tahun 2004 tentang Lembaga Penjamin Simpanan sebagaimana telah diubah dengan UndangUndang Nomor 7 Tahun 2009, LPS mempunyai fungsi:

a. menjamin simpanan nasabah penyimpan; dan

b. turut aktif dalam memelihara stabilitas sistem perbankan sesuai dengan kewenangannya.

Dalam menjalankan fungsinya yang pertama sebagaimana dimaksud di atas, LPS mempunyai tugas sebagai berikut:

a. merumuskan dan menetapkan kebijakan pelaksanaan penjaminan simpanan; dan

b. melaksanakan penjaminan simpanan. (Pasal 5 ayat (1))

Sedangkan dalam menjalankan fungsinya yang kedua sebagaimana dimaksud di atas, LPS mempunyai tugas sebagai berikut:

a. merumuskan dan menetapkan kebijakan dalam rangka turut aktif memelihara stabilitas sistem perbankan;

b. merumuskan, menetapkan, dan melaksanakan kebijakan penyelesaian Bank Gagal (bank resolution) yang tidak berdampak sistemik; dan

c. melaksanakan penanganan Bank Gagal yang berdampak sistemik. (Pasal 5 ayat (2))

Berdasarkan tugas yang dipunyainya, LPS mempunyai kewenangan untuk:

a. menetapkan dan memungut premi penjaminan;

b. menetapkan dan memungut kontribusi pada saat bank pertama kali menjadi peserta;

c. melakukan pengelolaan kekayaan dan kewajiban LPS; mendapatkan data simpanan nasabah, data kesehatan bank, laporan keuangan bank, dan laporan hasil pemeriksaan bank sepanjang 
tidak melanggar kerahasiaan bank;

d. melakukan rekonsiliasi, verifikasi, dan/atau konfirmasi atas data sebagaimana dimaksud pada huruf d;

e. menetapkan syarat, tata cara, dan ketentuan pembayaran klaim;

f. menunjuk, menguasakan, dan/atau menugaskan pihak lain untuk bertindak bagi kepentingan dan/atau atas nama LPS, guna melaksanakan sebagian tugas tertentu;

g. melakukan penyuluhan kepada bank dan masyarakat tentang penjaminan simpanan; dan menjatuhkan sanksi administratif.

Keberadaan LPS sebagaimana dimaksud di atas merupakan amanah dari Undang-Undang Nomor 10 tahun 1998 tentang perubahan atas Undang-Undang Nomor 7 Tahun 1992 tentang Perbankan (selanjutnya disebut dengan UU Perbankan). Dalam Pasal 37 B ayat (1) dan (2) UU Perbankan ditentukan bahwa:

(1) Setiap bank wajib menjamin dana masyarakat yang disimpan pada bank yang bersangkutan.

(2) Untuk menjamin simpanan masyarakat pada bank sebagaimana dimaksud dalam ayat (1) dibentuk Lembaga Penjamin Simpanan.

Sebagai tindak lanjut dari ketentuan Pasal 37 B UU Perbankan tersebut dibentuk Lembaga Penjamin Simpanan (LPS) yang bertujuan untuk melaksanakan penjaminan dana masyarakat dengan Undang-Undang Nomor 24 Tahun 2004 tentang Lembaga Penjamin Simpanan (UU LPS) yang diundangkan pada tanggal 22 September 2004 dan mulai berlaku efektif 12 bulan setelah diundangkan yaitu tanggal 22 September 2005. UU LPS tersebut kemudian diubah dengan PERPU No. 3 tahun 2008, dimana PERPU tersebut telah disahkan menjadi Undang-undang dengan dengan Undang-undang Nomor 7 Tahun 2009.

Pendirian LPS pada dasarnya dilakukan sebagai upaya memberikan perlindungan terhadap dua risiko yaitu irrational run terhadap bank dan systemic risk. Dalam menjalankan usaha bank biasanya hanya menyisakan sebagian kecil dari simpanan yang diterimanya untuk berjaga-jaga apabila ada penarikan dana oleh nasabah. Sementara, bagian terbesar dari simpanan yang ada dialokasikan untuk pemberian kredit. Keadaan ini menyebabkan perbankan tidak dapat memenuhi permintaan dalam jumlah besar dengan segera atas simpanan nasabah yang dikelolanya apabila terjadi penarikan secara tiba-tiba dan dalam jumlah besar. Keterbatasan dalam penyediaan dana cash ini karena bank tidak dapat menarik segera pinjaman yang telah disalurkannya. Bila bank tidak dapat memenuhi permintaan penarikan simpanan oleh nasabahnya, nasabah biasanya menjadi panik dan akan menutup rekeningnya pada bank dimaksud, sekalipun bank tersebut sebenarnya sehat. Sedangkan risiko sistemik terjadi apabila kebangkrutan satu bank berakibat buruk terhadap bank lain, sehingga menghancurkan segmen terbesar dari sistem perbankan. Dalam menjalankan tugasnya, LPS diharapkan dapat memelihara kepercayaan masyarakat terhadap industri perbankan dan dapat meminimumkan risiko yang membebani anggaran Negara atau risiko yang menimbulkan moral hazard. Dalam rangka terus meningkatkan kepercayaan publik kepada perbankan, peran 


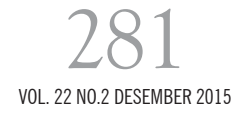

LPS bukan hanya sebagai lembaga yang menjamin simpanan nasabah bank namun juga untuk menjaga stabilitas sistem perbankan (Ichwan Kurnia, http://ichwan86kurnia.blogspot.com/2013/ 04/lembaga-penjamin-simpanan-lps-sebagai. html)

Penjaminan simpanan nasabah yang dilakanakan oleh LPS berlaku juga bagi bank syariah, sebagaimana ditentukan dalam Pasal 96 UULPS, yang berbunyi:

(1) LPS melaksanakan fungsi sebagaimana dimaksud dalam Pasal 4 bagi bank berdasarkan prinsip syariah.

(2) Ketentuan lebih lanjut mengenai pelaksanaan fungsi LPS sebagaimana dimaksud pada ayat (1) ditetapkan dalam Peraturan Pemerintah.

Ketentuan Pasal 96 UULPS tersebut di atas sejalan dengan ketentuan Pasal 54 ayat (2) UU Perbankan Syariah yang menyebutkan:

"Apabila tindakan sebagaimana dimaksud pada ayat (I) belum cukup untuk mengatasi kesulitan yang dialami

Bank Syariah, Bank Indonesia menyatakan Bank Syariah tidak dapat disehatkan dan menyerahkan penanganannya ke Lembaga Penjamin Simpanan untuk diselamatkan atau tidak diselamatkan.”

Pasal 1 angka 7 UU Nomor 21 Tahun 2008 tentang Perbankan Syariah menentukan bahwa Bank Syariah adalah bank yang menjalankan kegiatan usahanya berdasarkan Prinsip Syariah dan menurut jenisnya terdiri atas Bank Umum Syariah dan Bank Pembiayaan Rakyat Syariah. Selanjutnya menurut Pasal 1 angka 12 UU Nomor 21 Tahun 2008 tentang Perbankan Syariah, Prinsip Syariah adalah prinsip hukum Islam dalam kegiatan perbankan berdasarkan fatwa yang dikeluarkan oleh lembaga yang memiliki kewenangan dalam penetapan fatwa di bidang syariah. Dalam hal ini, lembaga sebagaimana dimaksud di atas adalah Dewan Syariah Nasional, yaitu suatu lembaga di bawah Majelis Ulama Indonesia.

Bank Syariah adalah bank yang bersifat khusus, artinya bank syariah tidak hanya tunduk pada ketentuan perbankan tetapi juga tunduk pada ketentuan-ketentuan syariah Islam. Keberadaan bank syariah di Indonesia pada dasarnya didorong adanya keyakinan bahwa bunga bank yang ada pada bank konvensional adalah riba dan itu berarti haram (Muhammad Syafii Antonio, 2001: 25). Berdasarkan hal di atas, kemunculan bank syariah dimaksudkan untuk menyediakan sarana perbankan bagi masyarakat yang mempunyai keyakinan bunga bank haram dan ingin menjalankan ajaran agama dengan sebenar-benarnya. Oleh karena itu bank syariah harus dapat menjamin kepada nasabahnya, baik nasabah investor maupun nasabah pembiayaan bahwa kegiatan yang dilakukannya tidak bertentangan dengan ketentuan syariah, sehingga bank syariah dapat menjamin kehalalan dari usaha dan kegiatan yang dilakukannya. Hal tersebut akan berdampak pada keuntungan yang diperoleh bank syariah juga halal secara syariah, keuntungan yang dibagi kepada nasabah investor juga halal secara syariah. Dengan demikian, bank syariah dapat melindungi kepentingan nasabah yang memilih bank syariah karena keinginannya mengikuti ketentuan agama, yaitu mencari yang halal dan meninggalkan yang haram (Danang Wahyu Muhammad, 2009: 43). 


\section{2}

JURNAL MEDIA HUKUM

Demikian juga bank syariah tidak diperkenankan mencampur dana yang berasal dari kegiatan syariah dengan dana-dana lain. Dalam Peraturan Bank Indonesia sudah ditentukan secara tegas, bahwa apabila ada bank konvensional yang membuka cabang syariah, maka dana bank syariah tersebut harus dibuatkan pembukuan sendiri. Artinya, tidak diperkenankan adanya percampuran berkaitan dengan pembukuan, sehingga nanti akan ada kejelasan berapa dana yang berasal dari unit syariah dan berapa dana yang berasal dari bank konvensional. Pasal 57 PBI Nomor 11/10/ PBI/2009 ditentukan bahwa:

(1) Bank Umum Konvensional (BUK) yang memiliki Usaha Unit Syariah (UUS) wajib menggunakan teknologi sistem informasi secara otomasi dan online yang dapat memisahkan secara jelas laporan keuangan UUS dengan laporan keuangan BUK.

(2) Penyusunan laporan keuangan UUS wajib mengikuti perlakuan akuntansi yang diatur dalam pedoman akuntansi perbankan syariah Indonesia yang berlaku.

Dalam melakukan pembiayaan, bank syariah tidak boleh melakukan pembiayaan terhadap usaha-usaha yang diharamkan secara syariah, di samping harus dengan menggunakan akad yang sesuai syariah. Demikian juga apabila bank syariah mempuyai kelebihan dana, maka dana lebih tersebut tidak boleh disimpan pada bank konvensional. Hal itu untuk menjaga kehalalan dana dan penghasilan dari bank syariah.

Sebagaimana telah disebutkan di atas, bahwa Bank syariah adalah bank yang selalu mendasarkan pada prinsip syariah sebagaimana yang telah ditentukan dalam Al-Qur'an, As-Sunnah dan ijtihad ulama dalam menjalankan kegiatan usahanya. Bank syariah hanya boleh menjalankan usaha yang dibolehkan (halal) dan menjauhkan diri dari perbuatan yang dilarang (haram) secara syariah.

Berkaitan dengan persoalan halal dan haram, Yusuf Al-Qaradhawi membuat prinsip-prinsip umum kegiatan ekonomi (Kuat Ismanto, 2009: 171). Berdasarkan kategori di atas, maka apa yang halal adalah juga pasti bermanfaat dan suci. Sementara apa yang tidak halal akan melukai kita. Diantara prinsip-prinsip tersebut adalah:

1) pada dasarnya diperbolehkannya segala sesuatu;

2) untuk membuat absah dan untuk melarang adalah hak Allah semata;

3) melarang yang halal dan membolehkan yang haram sama dengan syirik;

4) larangan atas segala sesuatu didasarkan atas sifat najis dan melukai;

5) apa yang halal adalah diperbolehkan, dan yang haram adalah dilarang;

6) menganggap yang haram sebagai halal adalah dilarang;

7) niat yang baik tidak membuat yang haram bias diterima;

8) hal-hal yang meragukan sebaiknya dihindari;

9) yang haram terlarang bagi siapapun;

10) keharusan menentukan adanya pengecualian.

Selanjutnya, dalam ketentuan Pasal 5 ayat (4) UU Perbankan Syariah yang berbunyi: "Bank Syariah yang telah mendapat izin usaha sebagaimana dimaksud pada ayat (1) wajib mencantumkan 
dengan jelas kata "syariah" pada penulisan nama banknya." Hal ini kemudian dipertegas dalam Pasal 13 Nomor: 11/03/2009 tentang Bank Umum Syariah. Ketentuan tersebut mempunyai banyak makna, antara lain untuk memberi peringatan kepada pihak bank bahwa dirinya membawa misi syariah. Dengan adanya kata "syariah" pada nama banknya, menjadikan bank tersebut wajib berhatihati dan selalu patuh pada prinsip syariah. Di samping itu, dengan pencantuman kata "syariah" pada nama bank syariah, maka hal itu membawa konsekuensi bahwa prinsip syariah selalu menjadi bagian dari bank syariah, termasuk pada saat bank syariah membuat perjanjian dengan pihak ketiga. Dengan demikian, maka bank syariah selalu terikat untuk tidak menyimpang dari prinsip syariah (Danang Wahyu Muhammad, 2012: 354).

Salah satu prinsip yang harus dipatuhi oleh Bank Syariah adalah menghindari dari perbuatan riba (Muhammad Syafii Antonio, 2001: 38). Ibnu al-Arabi al-Maliki dalam kitabnya 'Ahkam AlQur'an' menjelaskan, bahwa yang dimaksud riba adalah setiap penambahan yang diambil tanpa adanya satu transaksi pengganti atau penyeimbang yang dibenarkan menurut syariah (Muhammad Syafii Antonio, 2001: 38). Yang dimaksud dengan transaksi pengganti atau penyeimbang adalah transaksi bisnis atau komersial yang melegitimasi adanya penambahan tersebut secara adil, seperti transaksi jual beli, sewa atau bagi hasil proyek (Muhammad Syafii Antonio, 2001: 38). Yusuf al Qardlawi menyatakan bahwa dalam Islam tidak boleh melahirkan harta yang sama, uang tidak boleh melahirkan uang. Bahkan, harta seharusnya tumbuh dan berkembang dengan kerja dan memeras tenaga (Setiawan Budi Utomo, 2003: 51). Allah berfirman dalam Surat Al-Baqarah ayat 275 yang berbunyi: "Allah telah menghalalkan jual beli dan mengharamkan riba."

Riba menurut Islam hukumnya haram. Diharamkannya riba lebih didasarkan pada adanya unsur menindas. Apabila ada orang yang meminjam seribu, dalam jangka waktu satu tahun bisa menjadi seribu seratus. Dua tahun bisa menjadi seribu dua ratus. Tiga tahun menjadi seribu tiga ratus dan seterusnya Di sini ada unsur menindas terhadap orang yang meminjam (Zaim Saidi, http://www.islamlib.com).

Sehubungan dengan hal di atas, maka berdirinya Lembaga Penjamin Simpanan yang mewajibkan semua bank menjadi pesertanya menimbulkan masalah tersendiri. Apabila melihat UULPS, dapat diketahui LPS untuk saat ini masih dijalankan dengan sistem tunggal, yaitu dengan sistem konvensional. Padahal, dalam Pasal 8 ayat (1) UULPS ditentukan bahwa "Setiap Bank yang melakukan kegiatan usaha di wilayah Negara Republik Indonesia wajib menjadi peserta Penjaminan”. Berdasar ketentuan tersebut berarti bahwa kepesertaan LPS terdiri dari bank konvensional dan Bank Syariah.

Selanjutnya, dalam Pasal 9 huruf b dan c UULPS ditentukan bahwa setiap bank peserta penjaminan diwajibkan untuk membayar kontribusi kepesertaan sebesar 0,1\% (satu perseribu) dari modal sendiri (ekuitas) bank pada akhir tahun fiskal sebelumnya atau dari modal disetor bagi bank baru dan membayar premi Penjaminan.

Hal ini berarti dana penjaminan yang berasal dari bank konvensional akan bercampur dengan dana penjaminan yang berasal dari bank syariah. Demikian juga dalam pengelolaannya dilakukan 


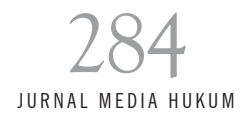

tanpa keharusan memperhatikan prinsip syariah.

Sebagaimana telah diketahui bahwa bank konvensional adalah bank yang menggunakan mekanisme bunga dalam menjalankan kegiatan usahanya. Bunga bank menurut fatwa Majelis Ulama Indonesia (MUI) termasuk dalam kategori riba, oleh karena itu haram secara syariah. Demikian juga Muhammadiyah, OKI dan sebagian besar ulama mengategorikan bunga bank sebagai riba. Berdasarkan kenyataan ini, maka ketentuan Pasal 9 huruf b dan c di atas berpotensi menimbulkan bercampurnya dana yang halal dengan dana yang diharamkan secara syariah.

Dana penjaminan simpanan yang berasal dari bank konvensional dan bank syariah nantinya akan dikelola dan dikembangkan oleh Lembaga Penjamin Simpanan. Pasal 82 UULPS menentukan bahwa kekayaan LPS berbentuk investasi dan bukan investasi. Kekayaan yang berbentuk investasi hanya dapat ditempatkan pada surat berharga yang diterbitkan oleh Pemerintah Indonesia dan/ atau Bank Indonesia. Surat berharga yang diterbitkan oleh Pemerintah Indonesia antara lain obligasi dan Surat Utang Negara (SUN). Sedangkan surat berharga yang diterbitkan oleh Bank Indonesia antara lain Sertifikat Bank Indonesia (SBI).

Baik obligasi, SUN maupun SBI pada umumnya menggunakan mekanisme bunga, meskipun untuk saat ini dikenal juga obligasi syariah, SUN syariah dan SBI syariah. Artinya, LPS dapat menginvestasikan kekayaannya dalam bentuk surat-surat berharga tersebut. Apabila demikian halnya, maka surplus yang diperoleh LPS dalam mengelola kekayaannya tidak selamanya halal secara syariah, dimungkinkan akan terjadi percampuran dana yang halal secara syariah dengan dana yang haram secara syariah.

Ketentuan di atas menunjukkan bahwa kekayaan LPS yang berasal dari kontribusi kepesertaan dan premi Penjaminan akan dikelola oleh LPS yang nantinya akan digunakan untuk melakukan investasi ataupun bukan investasi. Surplus yang diperoleh LPS dari kegiatan operasional sebagaimana dimaksud di atas selama 1 (satu) tahun akan dialokasikan sebagai berikut:

a. $20 \%$ (dua puluh perseratus) untuk cadangan tujuan;

b. $80 \%$ (delapan puluh perseratus) diakumulasikan sebagai cadangan penjaminan.

Surplus yang diperoleh LPS dari kegiatam operasional sebagaimana dimaksud di atas, nantinya akan digunakan oleh LPS dalam melakukan penjaminan dana nasabah. Artinya apabila ada klaim penjaminan simpanan dari nasabah bank yang telah dicabut izinnya LPS akan membayar klaim tersebut menggunakan dana surplus dari kegiatan operasional yang dilakukan oleh LPS. Bank Syariah yang mengalami masalah dan sudah ditangani oleh LPS akan mendapat dana penjaminan yang berasal dari dana yang bercampur dengan dan yang haram secara syariah.

Kaitannya dengan hal ini, ada kaedah syariah yang dapat dijadikan rujukan. Masalah halal yang sudah jelas, boleh saja dikerjakan. Persoalan haram pun yang sudah jelas, sama sekali tidak ada rukhsah (keringanan) untuk mengerjakannya, selama masih dalam keadaan normal. Hal ini sebagaimana dikemukakan oleh Syekh Muhammad Yusuf Qardhawi (Mu'ammal Hamidy, 1993 : 41). Rasulullah SAW., bersabda:

"Apa saja yang Allah halalkan dalam kitab-Nya, maka dia adalah halal, dan apa saja yang Allah 
haramkan, maka dia itu adalah haram; sedang apa yang Allah diamkan, maka dia itu dibolehkan (ma'fu). Oleh karena itu terimalah dari Allah kemaafannya itu, sesungguhnya Allah tidak akan lupa sedikitpun." (HR. Hakim dan Bazzar).

"Yang halal sudah jelas dan yang haram pun sudah jelas, di antara keduanya itu ada beberapa perkara yang belum jelas (syubhat), banyak orang yang tidak tahu apakah dia itu masuk bahagian yang halal ataukah yang haram? Maka barang siapa yang menjauhinya karena hendak membersihkan agama dan kehormatannya, maka dia akan selamat; dan barang siapa mengerjakan sedikit pun dari padanya hampir-hampir ia akan jatuh ke dalam haram, sebagaimana orang yang menggembala kambing di sekitar daerah larangan, dia hampir-hampir akan jatuh kepadanya. Ingatlah! Bahwa tiap-tiap raja mempunyai daerah larangan. Ingat pula, bahwa daerah larangan Allah itu adalah semua yang diharamkan."(HR. Bukhari, Muslim dan Tirmizi).

Dalam hal ini Allah SWT berfirman dalam QS. Al-An'am: I19: "Dan sungguh Allah telah menerangkan kepadamu apa-apa yang la haramkan atas kamu."

Salah satu prinsip yang telah diakui oleh Islam menurut Syekh Muhammad Yusuf AlQardlawi adalah apabila Islam telah mengharamkan sesuatu, maka wasilah dan cara apapun yang dapat membawa kepada perbuatan haram hukumnya adalah haram ((Mu'ammal Hamidy, 1993 : 35). Dari sinilah kemudian para ulama ahli fiqih membuat suatu kaedah, yaitu apa saja yang membawa kepada perbuatan haram, maka itu adalah haram.

Kaedah ini senada dengan apa yang diakui oleh Islam, yaitu bahwa dosa perbuatan haram tidak terbatas pada pribadi si pelakunya itu sendiri secara langsung, tetapi meliputi daerah yang sangat luas sekali, termasuk semua orang yang bersekutu dengan dia baik melalui harta ataupun sikap. Masing-masing mendapat dosa sesuai dengan keterlibatannya itu. Misalnya tentang arak, Rasulullah SAW melaknat kepada yang meminumnya, yang membuatnya, yang membawanya, yang diberinya, yang menjualnya, dan seterusnya. Demikian juga dengan riba.

Diriwayatkan oleh Muslim dari Jabir bin Abdillah, bahwa ia menceritakan, "Rasulullah melaknat pemakan riba, orang yang memberi makan dengan riba, juru tulis transaksi riba, dua orang saksinya, beliau bersabda, 'Semuanya sama saja'.” (HR. Muslim).

Semua yang dapat membantu kepada perbuatan haram, hukumnya haram juga. Dan semua orang yang membantu kepada orang yang berbuat haram, maka dia akan terlibat dalam dosanya juga (Mu'ammal Hamidy, 1993 : 35). Berdasarkan hadits di atas, tampak jelas bahwa sesuatu yang halal akan tampak halal dan sesuatu yang haram. Oleh karena itu, umat Islam dibolehkan atau bahkan diwajibkan melaksanakan yang halal dan dilarang melaksanakan sesuatu yang telah diharamkan.

Dalam sebuah media tanya jawab on-line dijelaskan, bahwa riba tidak terkena zakat. Antara riba dan zakat berada dalam dua sisi yang berbeda. Riba adalah sesuatu yang diharamkan, baik dalam Al-Quran maupun dalam As-Sunnah dan Ijtihad ulama. Sedangkan zakat sesuatu yang diwajibkan dan merupakan salah satu jenis ibadah. Bahkan, zakat merupakan salah satu rukun Islam, salah satu inti ibadah dalam Islam. Oleh karena itu, segala sesuatu yang berasal dari riba 


\section{6}

JURNAL MEDIA HUKUM

tidak dapat digunakan sebagai sarana melakukan ibadah (http://syariahonline.com/).

Hal yang sama terjadi pada Sunan Kalijaga. Pada masa mudanya, Sunan Kalijaga adalah seorang perampok yang terkenal dan ditakuti di kawasan Jawa Timur. Tetapi, dalam setiap melakukan aksinya, Raden Said selalu memilih korbannya dengan seksama. Raden Said hanya merampok orang kaya yang tak mau mengeluarkan zakat dan sedekah. Dari hasil rampokannya itu, sebagian besarnya selalu ia bagi-bagikan kepada orang miskin. Semuanya berubah saat Raden Said bertemu dengan seorang ulama yang bernama Syekh Maulana Makhdum Ibrahim alias Sunan Bonang. Sunan Bonang inilah yang kemudian mernyadarkannya bahwa perbuatan baik tak dapat diawali dengan perbuatan buruk - sesuatu yang haq tak dapat dicampuradukkan dengan sesuatu yang batil (http://www.uniquenews.net/ 2011/05/biografi-sunan-kalijaga-wali-songo.html).

Bahkan menurut Lajnah Ad-Daa-amah lil Bubuuts Al'Ilmiyyah Wal Iftaa' (Komite Tetap Kajian Fatwa Ilmiah dan Pemberian Fatwa) Kerajaan Saudi Arabia, secara tegas mengatakan bahwa membayar bunga pinjaman dengan menggunakan uang yang berasal dari bunga simpanan tidak diperkenankan (Syaikh Ahmad bin 'Abdurrazzaq Ad-Duwaisy sebagaimana diterjemahkan oleh M. Abdul Ghoffar, 2009: 392). Fatwa di atas mendasarkan pada ketentuan yang ada dalam AlQuran, antara lain dalam Surat Al-Baqarah 276, yang artinya: "Allah memusnahkan riba dan menyuburkan sedekah. Dan Allah tidak menyukai setiap orang yang tetap dalam kekafiran, dan selalu berbuat dosa."

Tampaknya, fatwa di atas ingin benar memisahkan antara yang halal dengan yang haram. Bahwa sesuatu yang halal tidak dapat dicampur dengan yang haram, demikian juga sebaliknya. Umat Islam dilarang memanfaatkan untuk memanfaatkan sesuatu yang bersumber dari yang haram, meskipun hal itu digunakan untuk sesuatu yang bersifat baik.

Hal yang sama juga berlaku juga untuk ketentuan Pasal 54 ayat (2) dan ayat (3). Sebagaimana diketahui bahwa Lembaga Penjamin Simpanan yang ada saat ini masih menjadi satu. Lembaga tersebut menjamin simpanan-simpanan yang ada pada bank konvensional dan simpanan-simpanan yang ada pada bank syariah. Artinya, peserta dari Lembaga Penjamin Simpanan adalah bank konvensional dan bank syariah. Apabila hal tersebut diberlakukan dengan serta merta, maka yang terjadi adalah adanya ketidakjelasan antara dana bank syariah dengan dana bank konvensional. Hal ini berarti ada kemungkinan dana yang diterima oleh nasabah bank syariah yang ikut dalam program penjaminan simpanan, ada ketidakjelasan, apakah dana tersebut halal secara syariah atau tidak. Oleh karena itu, perlu dipikirkan adanya lembaga penjamin simpanan syariah, yang mengakomodasi nasabah-nasabah yang ada pada bank syariah.

Sebagaimana diketahui, dalam UU No. 24 Tahun 2004 tentang Lembaga Penjamin Simpanan, sebagaimana telah diubah dengan UU No. 7 Tahun 2009, bahwa bank-bank yang ada di Indonesia yang ikut program Lembaga Penjamin Simpanan diwajibkan untuk membayar premi. Premi tersebut akan dikelola oleh Lembaga Penjamin Simpanan, yang nantinya digunakan oleh lembaga penjamin simpanan untuk membayar kepada nasabah bank, termasuk nasabah bank syariah, di mana banknya mengalami gagal bayar. 


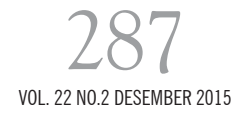

Bank syariah adalah bank yang bersifat khusus, artinya dana bank syariah tidak diperkenankan bercampur dengan dana yang non syariah. Dalam UU PS juga sudah ditentukan, bahwa apabila ada bank konvensional yang membuka cabang syariah, maka dana bank syariah tersebut harus dibuatkan pembukuan sendiri. Artinya, tidak diperkenankan adanya percampuran berkaitan dengan pembukuan, sehingga nanti akan ada kejelasan berapa dana yang berasal dari unit syariah dan berapa dana yang berasal dari bank konvensional. Ini merupakan salah satu sikap kehati-hatian yang harus dilakukan oleh bank syariah, agar nanti pada saat bank syariah mengalami sesuatu hal yang berakibat harus disehatkan dan diserahkan penanganannya ke Lembaga Penjamin Simpanan, dana yang masuk ke dalam bank syariah, termasuk untuk menalangi dana tidak tercampur dengan dana yang menurut syariah haram.

Selanjutnya, dalam ketentuan Pasal 5 ayat (4) UU Perbankan Syariah yang berbunyi: "Bank Syariah yang telah mendapat izin usaha sebagaimana dimaksud pada ayat (1) wajib mencantumkan dengan jelas kata "syariah" pada penulisan nama banknya." Ketentuan tersebut mempunyai banyak makna, antara lain untuk memberi peringatan kepada pihak bank bahwa dirinya membawa missi syariah. Dengan adanya kata "syariah" pada nama banknya, menjadikan bank tersebut wajib berhatihati dan selalu patuh pada prinsip syariah. Di samping itu, dengan pencantuman kata "syariah" pada nama bank syariah, maka hal itu membawa konsekuensi bahwa prinsip syariah selalu menjadi bagian dari bank syariah, termasuk pada saat bank syariah membuat perjanjian dengan pihak ketiga. Dengan demikian, maka bank syariah selalu terikat untuk tidak menyimpang dari prinsip syariah.

Berkaitan dengan ketentuan Pasal 54 ayat (1) huruf e; huruf $\mathrm{f}$ dan huruf $g$, bank syariah harus berhati-hati sehingga kepentingan nasabah penyimpan dapat terlindungi, berkaitan dengan penerapan prinsip syariah. Bank syariah adalah pihak yang mendapatkan amanah dari pihak nasabah untuk mengelola dana nasabah sesuai dengan prinsip syariah. Maka sudah menjadi kewajiban dari pemilik bank syariah untuk mencari pihak yang benar-benar dapat melakukan kegiatan syariah atau bahkan dapat mencari orang yang tahu ilmu fikih sehingga kepentingan nasabah menjadi terlindungi.

Pengaturan tentang sumber yang halal ini menjadi sangat penting, sebab kalau tidak, bank syariah akan bisa digunakan sebagai sarana untuk melakukan "pencucian uang syariah". Artinya, uang yang semula haram secara syariah diinvestasikan ke dalam bank syariah dan nanti seakanakan dana tersebut menjadi halal secara syariah. Atau sebaliknya, uang yang semula halal secara syariah, oleh bank syariah diinvestasikan ke dalam usaha yang diharamkan secara syariah atau diinvestasikan dengan cara-cara yang tidak dibenarkan secara syariah, maka dana tersebut akan menghasilkan sesuatu yang haram secara syariah.

Berdasarkan uraian di atas, LPS diharapkan dapat memelihara kepercayaan masyarakat terhadap industri perbankan dan dapat meminimumkan risiko yang membebani anggaran Negara atau risiko yang menimbulkan moral hazard. Dalam rangka terus meningkatkan kepercayaan publik kepada perbankan, peran LPS bukan hanya sebagai lembaga yang menjamin simpanan nasabah 
bank namun juga untuk menjaga stabilitas sistem perbankan (Ichwan Kurnia, http://ichwan86 kurnia.blogspot.com/2013/ 04/lembaga-penjamin- simpanan-lps-sebagai.html).

Keberadaan LPS sangat penting untuk menjamin stabilitas perbankan. Tahun 1998 kita sudah mengalami pil pahit devaluasi kurs yang mengakibatkan bank mengalami rush dan menghancurkan perekonomian Indonesia. Sepuluh tahun kemudian kita sudah memetik hasilnya. Indonesia tercatat mengalami pelemahan kurs pada november 2008 dan Februari 2009, namun tidak diikuti oleh penarikan DPK besar-besaran oleh pihak ketiga. Hal ini dikarenakan masyarakat makin percaya diri terhadap ekonomi Indonesia, dan juga karena dukungan penjaminan yang diberikan LPS (Agustianto, http://www.neraca.co.id/article/ 28443/Lembaga-Penjaminan-Simpanan-Syariah-danJaminan-Keamanan-Nasabah Perbankan-Syariah).

Memang sekarang di Indonesia sudah mempunyai Peraturan Pemerintah Republik Indonesia Nomor 39 Tahun 2005 tentang Penjaminan Simpanan Nasabah Bank Berdasarkan Prinsip Syariah yang ditetapkan pada tanggal 12 Oktober 2005. Akan tetapi kalau dilihat dari isinya tidak mencerminkan prinsip-prinsip syariah. Peraturan Pemerintah tersebut hanya terdiri dari 4 (empat) pasal, di mana tidak ada satu pasal pun yang mengatur tentang cara penjaminan, perjanjian antara bank syariah dengan LPS, dan cara pengelolaan dana LPS. Padahal itu semua yang akan menentukan apakah dana LPS tersebut nantinya halal atau haram secara syariah.

Misalnya, dalam Pasal 3 PP Nomor 39 Tahun 2005 menentukan bahwa:

"Simpanan nasabah bank berdasarkan Prinsip Syariah yang dijamin oleh LPS sebagaimana dimaksud dalam Pasal 2 berbentuk:

a. giro berdasarkan Prinsip Wadiah;

b. tabungan berdasarkan Prinsip Wadiah;

c. tabungan berdasarkan Prinsip Mudharabah muthlaqah atau Prinsip Mudharabah muqayyadah yang risikonya ditanggung oleh bank;

d. deposito berdasarkan Prinsip Mudharabah muthlaqah atau Prinsip Mudharabah muqayyadah yang risikonya ditanggung oleh bank; dan/atau

e. Simpanan berdasarkan Prinsip Syariah lainnya yang ditetapkan oleh LPS setelah mendapat pertimbangan LPP."

Sementara itu, Pasal 2 dari PP tersebut menentukan sebagai berikut:

"Lembaga Penjamin Simpanan, yang selanjutnya disebut LPS, menjamin Simpanan nasabah bank berdasarkan

Prinsip Syariah sesuai dengan ketentuan dalam Undang-Undang Nomor 24 Tahun 2004 tentang Lembaga Penjamin Simpanan."

Selanjutnya, dalam penjelasan Pasal 2 PP Nomor 39 tahun 2005 dijelaskan bahwa:

“Berdasarkan ketentuan pasal ini, LPS menjamin Simpanan nasabah dari bank berdasarkan Prinsip Syariah, baik bank umum dan Bank Perkreditan Rakyat yang melaksanakan kegiatan usaha berdasarkan Prinsip Syariah, maupun Unit Usaha Syariah (UUS) dari bank konvensional.

Seperti halnya kantor cabang, UUS merupakan bagian yang tidak terpisahkan dari bank induknya. Untuk 


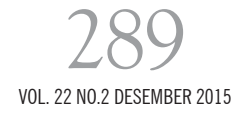

itu, tidak ada persyaratan kepesertaan yang harus dipenuhi oleh UUS karena persyaratan kepesertaan merupakan kewajiban yang harus dipenuhi bank konvensional yang menjadi induk dari UUS tersebut. Demikian pula apabila izin UUS dicabut oleh Lembaga Pengawas Perbankan (LPP), baik atas permintaan pemegang saham maupun karena pengenaan sanksi dari LPP, maka kewajiban kepada nasabah penyimpan menjadi tanggung jawab bank induk dari UUS tersebut."

Terkait dengan pelaksanaan penjaminan simpanan, Pasal 2 PP Nomor 39 tahun 2005 menunjuk UU LPS sebagai dasar pelaksanaannya. Hal ini akan berpotensi menimbulkan polemik seperti yang terjadi pada BPJS Kesehatan. Sempat beredar kabar bahwa BPJS Kesehatan haram. Polemik tersebut berdasarkan pada kajian MUI bahwa dalam BPJS masih ada bunga, ada akad yang tidak sesuai syariah, dan dana BPJS diinvestasikan ke mana. Padahal sebelum BPJS berdiri Dewan Syariah Nasional (DSN) MUI telah mengeluarkan fatwa yang sebenarnya bisa dijadikan rujukan oleh BPJS dalam menjalankan usahanya. Fatwa-fatwa tersebut antara lain (Irfan Nofiandana, http://www.arrahmah.com/ kontribusi/sebelum-salahkan-mui-baca-ini-dulu-tidak-ada-fatwa-harambpjs.html):

a. Fatwa DSN-MUI No. 21 tentang Pedoman Asuransi Syariah;

b. Fatwa DSN-MUI No. 43 tentang ganti rugi (ta'widh);

c. Fatwa DSN-MUI No. 52 tentang Akad Wakalah Bil Ujrah Pada Asuransi Syari'ah dan Reasuransi Syari'ah.

Berdasarkan kejadian tentang polemik BPJS tersebut di atas, pemerintah harus memisahkan antara LPS untuk bank konvensional dengan LPS untuk bank syariah. Faktanya di Indonesia berdasarkan prinsip operasionalnya, ada dua jenis bank, yaitu bank konvensional dan bank syariah. Antara kedua jenis bank tersebut terdapat perbedaan yang sangat mendasar, yaitu berkaitan dengan bunga. Bank konvensional dalam menjalankan kegiatan usahanya menggunakan bunga, sedangkan bank syariah tidak menggunakan bunga tetapi menggunakan prinsip bagi hasil dan prinsip-prinsip lain yang sesuai dengan syariah, karena bunga menurut konsep Islam termasuk riba yang diharamkan.

Pemisahan sebagaimana dimaksud di atas, dapat dilakukan dengan mendirikan LPS sendiri yang mendasarkan pada prinsip syariah. Atau dapat juga dilakukan dengan mengadopsi yang ada pada perbankan, yaitu dengan window system. Arinya, LPS yang ada menjalankan penjaminan dengan dua prinsip sekaligus, yaitu konvensional yang didalamnya ada unit syariahnya. Apabila window system ini yang dipilih, maka ketentuannya sama dengan perbankan, yaitu ada pembukuan yang terpisah antara pembukuan konvensional dengan pembukuan yang menggunakan prinsip syariah, sehingga dapat dihindari adanya percampuran antara dana LPS konvensional dan dana LPS syariah.

Untuk operasionalnya, karena pada dasarnya LPS menggunakan mekanisme asuransi dalam menjalankan usahanya, maka LPS syariah harus mendasarkan pada fatwa DSN MUI di bidang asuransi sebagaimana dimaksud di atas. Di samping itu, LPS syariah dalam mengelola dana hanya 


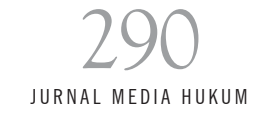

diperkenankan melakukan investasi pada hal-hal yang diperbolehkan secara syariah. Kalau akan digunakan untuk membeli surat berharga, maka hanya obligasi syariah, SBI syariah, saham syariah dan surat berharga lain yang memang diperbolehkan.

Dalam sebuah wawancara dengan Dr. Khaerudin Hamsin pada tanggal 12 September 2015, beliau mengatakan:

"LPS sangat diperlukan dalam dunia perbankan, termasuk dalam perbankan syariah untuk menjaga kepercayaan masyarakat. Akan tetapi perlu dipikirkan adanya LPS khusus untuk bank syariah, sehingga akan terdapat konsistensi berkaitan dengan penerapan syariah. LPS tersebut nantinya menggunakan akad syariah, dikelola secara syariah, dananya diinvestasikan secara syariah. Dengan demikian akan menjaga kepentingan semua pihak yang ingin menjalankan agama secara benar."

Terkait dengan sistem LPS di perbankan syariah di Indonesia, LPS Indonesia dapat mengikuti pola penjaminan yang dilakukan Malaysia. Malaysia Deposit Insurance Corporation (MDIC) melakukan pembedaan penjaminan pada bank syariah dan bank umum. Hal ini sebetulnya dapat ditiru karena bank syariah memiliki risiko yang berbeda dengan bank konvensional. Apalagi perbankan syariah tidak menggunakan bunga. Menciptakan Lembaga Penjaminan Simpanan yang sesuai syariah sangat-lah mudah, yaitu hanya memisahkan (dalam arti mengelompokan) dana ta'awun yang diperoleh LPS dari peserta yang dibedakan dari dana premi yang diterima dari konvensional (Agustianto, http://www.neraca.co.id/article/28443/Lembaga-PenjaminanSimpanan-Syariah-dan-Jaminan -Keamanan-Nasabah-Perbankan-Syariah).

\section{G. SIMPULAN}

Berdasarkan pembahasan dan analisis, maka dapat disimpulkan, bahwa: Prinsip operasional perbankan di Indonesia terdapat dua jenis bank, yaitu bank konvensional dan bank syariah, di mana ke dua jenis bank tersebut menggunakan sistem yang berbeda. Oleh karena itu secara prinsip harus dibedakan lembaga yang menjamin simpanan nasabahnya. Hal ini berdasarkan pada pertimbangan:

1. Bank syariah mengharamkan bunga dan oleh karena itu tidak menggunakan mekanisme bunga dalam operasionalnya, maka seharusnya Lembaga yang menjamin simpanan nasabahnya pun juga tidak menggunakan mekanisme bunga.

2. Bank syariah dalam operasionalnya menggunakan akad yang sudah ditentukan dalam fikih Islam, maka Lembaga yang menjamin simpanan nasabahnya pun juga harus mendasarkan pada akad yang ditentukan dalam fikih Islam.

3. Bank syariah terikat dengan ketentuan apa yang boleh dilakukan dan tidak boleh dilakukan berdasarkan ketentuan fikih Islam, maka Lembaga yang menjamin simpanan nasabahnya pun juga harus mendasarkan pada ketentuan yang sama.

Dengan demikian akan ada konsistensi antara bank syariah dengan lembaga yang menjamin simpanan dana yang ada pada bank syariah, yang pada akhirnya akan menjamin perlindungan 
terhadap nasabah yang ingin menjalankan agama dengan baik dan benar.

\section{DAFTAR PUSTAKA}

Abdullah Saeed, 1996, Islamic Banking And Interest; A Study of The Prohibitation of Riba And Its Contemporary Interpretation, EJ. Brill Leiden, New York - Koln, diterjemahkan oleh Muhammad Ufuqul Mubin, et. all, 2008, Bank Islam dan Bunga; Studi Kritis Larangan Riba Dan Interpretasi Kontemporer, Yogyakarta, Pustaka Pelajar.

Adiwarman A. Karim, 2007, Ekonomi Makro Islam, PT. RajaGrafindo Persada, Jakarta, Ahmad

Dimyati, 2008, Teori Keuangan Islam: Rekonstruksi Metodologis Terhadap Teori Keuangan al-Ghazali, Yogyakarta, UII Press.

Ahmad Dimyati, 2008, Teori Keuangan Islam; Rekonstruksi Metodologi Terhadap Teori Keuangan AlGhazali, Yogyakarta, UII Press.

Ali Hasan, 2009, Manajemen Bisnis Syariah; Kaya di Dunia, Terhormat di Akhirat, Yogyakarta, Pustaka Pelajar.

Ascarya, 2008, Akad dan Produk Bank Syariah, Jakarta, PT. RajaGrafindo Persada.

Aziz, 1992, Mengembangkan bank Islam di Indonesia Buku 1, Jakarta, Bangkit.

Bruggink, JJ.,H.,tt., Rechts-Reflecties, diterjemahkan oleh Arif Sidharta, 1996, Refleksi Hukum, Bandung, PT. Citra Aditya Bakti.

Danang Wahyu Muhammad, 2009, Perlindungan Terhadap Nasabah Penyimpan Dana Pada Bank Syariah, Hasil Penelitian, Dosen Muda, Depdiknas.

, 2012, Konsep Falah Dalam Pengaturan dan Pembuatan Kontrak Pada Bank Syariah, Disertasi, Program Doktor Ilmu Hukum, Program Pascasarjana, Universitas Diponegoro, Semarang.

2014, Penerapan Prinsip Syariah Dalam Permodalan Bank Syariah, Jurnal Media Hukum, Vol. 21, No. 1

Frank E. Vogel \& Samuel L. Hayes, 1998, Islamic Law And Finance: Religion, Risk And Return, diterjemahkan oleh M. Sobirin Asnawi, dkk.,2007, Hukum Keuangan Islam: Konsep, Teori Dan Praktek, Bandung, Nusamedia.

Gemala Dewi, 2004, Aspek-Aspek Hukum dalam Perbankan EO Perasuransian Syariah di Indonesia, Jakarta, Prenada Media.

Johnny Ibrahim, 2007, Teori dan Metodologi Penelitian Hukum Normatif, Malang, Bayumedia Publishing.

Karnaen Perwataatmadja \& Muhammad Syafi'I Antonio, 1992, Apa dan Bagaimana Bank Islam, Yogyakarta, Dana Bhakti Wakaf.

Muhammad, 2000, Lembaga-Lembaga Keuangan Umat Kontemporer, Yogyakarta, UII Press.

Muhammad Syafi'I Antonio, 2001, Bank Syariah, Dari Teori Ke Praktek, Jakarta, Gema Insani.

Nurul Huda, et.all., 2008, Ekonomi Makro Islam: Pendekatan Teoritis, Jakarta, Kencana Prenada Media Group. 


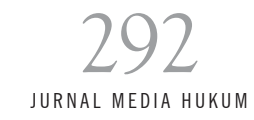

Peter Mahmud Marzuki, 2005, Penelitian Hukum, Jakarta, Prenada Media.

Ronny Hanitijo Soemitro, 1988, Metodologi Penelitian Hukum dan Jurimetri, Jakarta, Ghalia Indonesia.

Soerjono Sukanto dan Sri Mamudji, 2002, Penelitian Hukum Normatif, Suatu Tinjauan Singkat, Jakarta, Radja Grafindo.

Subagyo, at.all.,2002, Bank dan Lembaga Keuangan Lainnya, Yogyakarta, STIE YKPN.

Syaikh Ahmad bin 'Abdurrazzaq Ad-Duwaisy (pengumpul dan penyusun), 1999, Fataawaa AlLajnah Ad-Daaimah lil Buhuuts Al-'Ilmiyyah Wal Iftaa' - Al-Buyuu' (1), Daarul "Ashimah Riyadh Saudi Arabia, diterjemahkan oleh M. Abdul Ghoffar, 2009, Fatwa-Fatwa Jual Beli Oleh UlamaUlama Besar Terkemuka, Bogor, Pustaka Imam Asy-Syafi'i.

Syekh Muhammad Yusuf Qardhawi, 1980, al-Halal wa al-Haram fi al-Islam, diterjemahkan oleh H. Mu'ammal Hamidy, 1993, Halal dan Haram Dalam Islam, PT. Bina Ilmu.

Tim Pusat Pengkajian dan Pengembangan Ekonomi Islam (P3EI) UII bekerja sama dengan Bank Indonesia, 2008, Ekonomi Islam, Jakarta, PT. Raja Grafindo Persada.

Umer Chapra, M, \& Khan, Tariqullah, 2000, Regulation and Supervision of Islamic Banks, Occasional Paper No. 3, Jeddah, Saudi Arabia: Islamic Research and Training Institute: Islamic Development Bank.

Veithzal Rivai, H, \& Andi Buchari, 2009, Islamic Economics; Ekonomi Syariah Bukan Opsi, Tetapi Solusi, Jakarta, PT. Bumi Aksara.

Warkum Sumitro, 2002, Asas-Asas Perbankan Islam dan Lembaga-Lembaga Terkait, BMI dan Takaful di Indonesia, Jakarta, Raja Grafindo Persada.

Yusuf Al-Qaradhawi, Al-Halal wa Al-Haram fi Al-Islam, Indianapolis, USA: American Trust Publications, hlm. 50, dalam Kuat Ismanto, 2009, Asuransi Syari'ah, Tinjauan Asas-Asas Hukum Islam, Yogyakarta, Pustaka Pelajar.

Yusuf al-Qaradhawi, 2003, Fawaid al-Bunuk Hiya ar-Riba al-Haram, diterjemahkan oleh Setiawan Budi Utomo, Bunga Bank Haram, Akbar, Jakarta, Media Eka Sarana.

Zamir Iqbal \&Abbas Mirakhor, An Introduction To Islamic Finance: Theory And Practice, alih bahasa oleh A.K. Anwar, 2008, Pengantar Keuangan Islam: Teori dan Praktek, Jakarta, Kencana Prenada Media Group.

Zainuddin Ali, 2008, Hukum Ekonomi Syariah, Jakarta, Sinar Grafika.

Agustianto, Lembaga Penjaminan Simpanan Syariah dan Jaminan Keamanan Nasabah Perbankan Syariah, http://www.neraca.co.id/article/28443/Lembaga-Penjaminan-Simpanan-Syariah-dan-JaminanKeamanan-Nasabah-Perbankan-Syariah, diunduh tanggal 24 april 2015, jam 03.18

Anonim, Riba Tidak Terkena Zakat, suatu tanya jawab, http://syariahonline.com/, diunduh tanggal 24 april 2015, jam 23.57.

—, Biografi Sunan Kalijaga - Wali Songo, http://www.uniquenews.net/ 2011/05/ biografisunan-kalijaga-wali-songo.html, diunduh tanggal 18 Juni 2015, jam 6.27.

, Aturan Skema Syariah Memerlukan Lembaga Penjamin Simpanan (LPS), http://zonaekis.com/ 


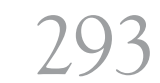

VOL. 22 NO.2 DESEMBER 2015

aturan-skema-syariah-memerlukan-lembaga-penjamin-simpanan lps/, dipublish oleh Choir, diunduh tanggal 27 April 2015, jam 23.38

Ichwan Kurnia, Lembaga Penjamin Simpanan (LPS) Sebagai Salah Satu Instrumen Pengembalian Kepercayaan Masyarakat Terhadap Instansi Perbankan Ditinjau Berdasarkan Undang-Undang Lembaga Penjamin Simpanan, http://ichwan86kurnia.blogspot.com/2013/04/lembaga-penjaminsimpanan-lps sebagai.html, diunduh tanggal 24 april 2015, jam 01.31.

Irfan Noviandana, Sebelum Salahkan MUI, Baca Ini Dulu: Tidak Ada Fatwa Haram BPJS, http:// www.arrahmah.com/kontribusi/sebelum-salahkan-mui-baca-ini-dulu-tidak-ada-fatwa-harambpjs.html, diunduh tanggal 18 oktober 2015, jam 10.21.

Zaim Saidi, Bebas Bunga, Tak Berarti Bebas Riba, http://www.islamlib.com, tanggal 22-12-2003. 